\title{
Correction: Disruption of the retinoblastoma pathway by small interfering RNA and ectopic expression of the catalytic subunit of telomerase lead to immortalization of human ovarian surface epithelial cells
}

\author{
G. Yang • D. G. Rosen · J. A. Colacino - I. Mercado-Uribe · J. Liu
}

Published online: 17 April 2020

๑) Springer Nature Limited 2020

Correction to: Oncogene

https://doi.org/10.1038/sj.onc.1209905

Following the publication of this Article the authors noted some concerns from readers regarding the Figures published and offer the following explanation.

The immortalization of ovarian surface epithelial cells using siRNAs against p53 or Rb in combination with hTERT were separately published in two journals (Oncogene, 2007 Mar 1; 26(10): 1492-8 and Carcinogenesis, 2007 Jan 1; 28(1): 174-82). The immortalization experiments using both vectors were performed at the same time, the experiments that characterized these cell lines including telomere length, western blots, telomerase activity (TRAP assay) were done using the same gel, and animal assays were performed at the same time using the same positive control. Therefore, the same positive/negative controls and markers were used for both Articles.

Specifically:

- The negative control and DNA marker were the same for Onc-Fig. 3f and Car-Fig. 4a.

- Control cell OSE137, control DNA (low and high), and DNA marker were the same for Onc-Fig. $3 g$ and CarFig. 4b.

- Protein bands of p53, pRb, p15, p16, p27, cdk2, Cyclin D1 and actin in OSE137 parental and parental IR cells were the same between Onc-Fig. 4e and Car-Fig. 6.

- Colony formation and tumor growth of T29H cells were same between Onc-Fig. 5a-b and Car-Fig. 7a.

The scientific conclusions of both Articles remain unaffected. 